\title{
Seed size distribution, germination, and emer- gence of 6 switchgrass cultivars
}

\author{
GLEN E. AIKEN AND TIMOTHY L. SPRINGER
}

Authors are research agronomists, USDA-ARS, South Central Family Farm Research Center, 6883 State Highway 23 South, Booneville, Ark. 72927-9214.

\begin{abstract}
Switchgrass (Panicum virgatum L.) has potential as a forage and biomass crop, but difficult establishment has limited its use. Germination and emergence were studied for 6 cultivars of switchgrass ('Alamo', 'Blackwell', 'Cave-in-Rock', 'Kanlow', 'Pathfinder', and 'Trailblazer'). Germination studies were conducted to determine the effect of light on germination and coleoftile length, and to determine the effect of seed size $(40,50$, 60,70 , and $50^{\circ}$ air valve settings for a South Dakota seed blower) on germination. A greenhouse study was also conducted to examine the effect of seed size, planting depth, $(5,10$, and $20 \mathrm{~mm})$, and sail type (sand and 2 silt loams) on emergence. Germination of unsized seed increased linearly as duration in the germination chamber increased from 7 to 21 days for all cultivars. Although presence of light did not affect germination, coleoptile length under continuous darkness averaged $4.1 \mathrm{~cm}$ and was greater than the $1.0 \mathrm{~cm}$ measured for those with daily light exposure of 16 hours. Both germination and emergence increased nonlinearly as seed size increased. For both silt-loam soils, emergence was low ard not affected by planting depth. A nonlinear decline in emergence with increased planting depth was detected in sand 7 days after planting, but not after 14 and 21 days. Results of the stady indicate that seed size and soil texture had a greater effect on emergence than did planting depth down to a depth of $20 \mathrm{~mm}$.
\end{abstract}

Key Word̀s: Gramineae, native grasses, Panicum virgatum L., coleoptile

Switchgrass (Panicum virgatum L.) is a highly productive perennial that is adapted to much of the central and eastern USA. There is considerable interest in switchgrass as both a forage and a biomass crop, but slow and inconsistent establishment has limited its commercial use. A correlation between seed weight and seedling vigor has been reported for numerous native grasses (Rogler 1954, Kneebone and Cremer 1955, Kittock and Patterson 1962, Glewen and Vogel 1984). Boe and Johnson (1987) specu-

The authors express appreciation to Mr. Herbert Huneycutt (retired) of the Arkansas Agriculture Experiment Station for providing the germplasm used in the study,

Manuscript accepted 16 Feb. 1995. lated that seed size should be a selection criteria for improving the seedling vigor of switchgrass. Although Jensen and Boe (1991) found considerable variation in seed size, a relationship between seed size and either germination or seeding vigor was not determined.

The purpose of this study was to determine whether seed size can be exploited as a means of improving switchgrass establishment. The objectives were to examine: (1) the effect of light and duration in the germination chamber on germination and coleoptile length, (2) the relationship between seed size and germination, and (3) the effect of seed size on emergence for 6 cultivars of switchgrass planted at different depths and in different soil types. The cultivars studied were 2 lowland types, Alamo and Kanlow, and 4 upland types, Blackwell, Cave-in-Rock, Pathfinder, and Trailblazer.

\section{Materials and Methods}

\section{Germination and Coleoptile Length for Unsized Seed}

Fifty seeds of each cultivar were placed in $7 \times 7 \mathrm{~cm}$ sealed plastic germination boxes on doubled-layered paper towels moistened with distilled water. The boxes were placed in a germination chamber set for alternating temperatures of $20^{\circ} \mathrm{C}$ for 16 hours (dark) and $30^{\circ} \mathrm{C}$ for 8 hours (light). A continuous darkness treatment was imposed by wrapping individual boxes with aluminum foil. Treatment combinations were arranged in a randomized complete block design with 4 replications within the germination chamber. Cumulative germination counts were made after $7-, 14-$, and 21-days. There were separate germination boxes used for each cultivar $\times$ light-dark exposure $\times$ duration time combination. Germination was determined to have occurred when the radicle reached $2 \mathrm{~mm}$ in length. Following each germination count, 10 coleoptiles were chosen randomly from each box for measurement of length.

\section{Seed Size Distribution}

Four random, 5-g samples of seed were taken for each cultivar. Each sample was separated into 5 seed size classes using a South Dakota seed blower Air valve settings of 40,50,60,70, and $80^{\circ}$ were used for the separations. Seed of each cultivar and size class combination were subsequently weighed and counted, using an electronic seed counter. 


\section{Germination and Emergence of Sized Seed}

Germination was determined for 25 seed of each size class of cultivars following the same procedure as for the unsized seed, except that no continuous darkness treatment was used.

For each cultivar, 25 seed of each of 3 size classes $(50,60$, and $70^{\circ}$ air valve sertings) were planted in pots in a greenhouse at 3 depths $(5,10$, and $20 \mathrm{~mm})$ in either sand or in topsoil of 2 different silt loams (Leadvale-fine silty, siliceous, thermic Typic Fragiudult; and Taft-fine silty, siliceous, thermic Typic Flossaquic Fragiudult). Low seed numbers for the lowest and highest size classes made it necessary to limit testing to only the 3 intermediate size classes. Treatments were arranged in a split plot (4 splits) design with 4 replications. Cultivar was the main plot and the order of the split plots was size, soil, and planting depth. The pots were watered twice daily at 12 -hour intervals using an automatic sprinkler. Emergence was counted after 7-, 14-, and 21-days.

\section{Statistical Analysis}

All percentage data were transformed using an arcsine function before analysis. Germination and coleoptile length as a function of time for unsized seeds, and germination and emergence responses to seed size and soil type were analyzed using orthogonal polynomials to determine linear, quadratic, and cubic trends (Steel and Torrie, 1980). Determination of significant orthogonal polynomials for all simple effect comparisons followed GLM procedures for SAS described by Littell et al. (1991).

\section{Results}

\section{Germination and Coleoptile Length for Unsized Seed}

Germination percentage increased linearly with time for all cultivars, except for Trailblazer and Kanlow (Table 1). Presence or absence of light did not affect germination $(P>0.1)$, but did

Table 1. Germination of unsized seed for 6 cultivars of switchgrass as affected by duration in the germination chamber.

\begin{tabular}{|c|c|c|c|c|c|}
\hline \multirow[b]{2}{*}{ Culaviar } & \multicolumn{3}{|c|}{ Duration } & \multirow[b]{2}{*}{ SEM } & \multirow[b]{2}{*}{ F test ${ }^{1}$} \\
\hline & 7 & 14 & 21 & & \\
\hline & $\ldots$ & $-\not b-$ & $\ldots$ & & \\
\hline Alamo & 63.0 & 69.2 & 77.0 & 2.0 & $\mathrm{~L}_{* \neq}^{\neq \cdots *}$ \\
\hline Blackwell & 57.0 & 63.0 & 67.5 & 1.6 & $\mathrm{~L}^{*}$ \\
\hline Cave-in-Rock & 52.5 & 65.7 & 69.7 & 1.9 & $L^{*}$ \\
\hline Kanlow & 49.5 & 72.7 & 70.0 & 2.5 & $L^{\neq \neq \neq}, Q^{* \neq *}$ \\
\hline Pathfinder & 79.0 & 89.7 & 94.0 & 1.7 & $L^{* * *}$ \\
\hline Trailblazer & 78.5 & 82.7 & 81.5 & 1.3 & $\mathrm{NS}^{2}$ \\
\hline
\end{tabular}

Linear (L) and guadratic (Q) responses.

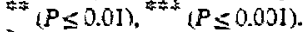

2 Not significant $(P \geq 0.1)$.

affect coleoptile length. Coleoptiles grown under continuous darkness were longer $(P<0.001)$ than those grown with light exposure. Mean coleoptile length at 21 days was $0.9 \mathrm{~cm}$ (SEM = 0.03 ) for continuous light and $4.7 \mathrm{~cm}$ (SEM $=0.2$ ) for the continuous-darkness treatment. For continuous darkness, all cultivars showed a nonlinear increase in coleoptile length between the 7and 21-day durations (Table 2).
Table 2. Coleoptile length for 6 cultivars of switchgrass as affected by duration in the germination chamber.

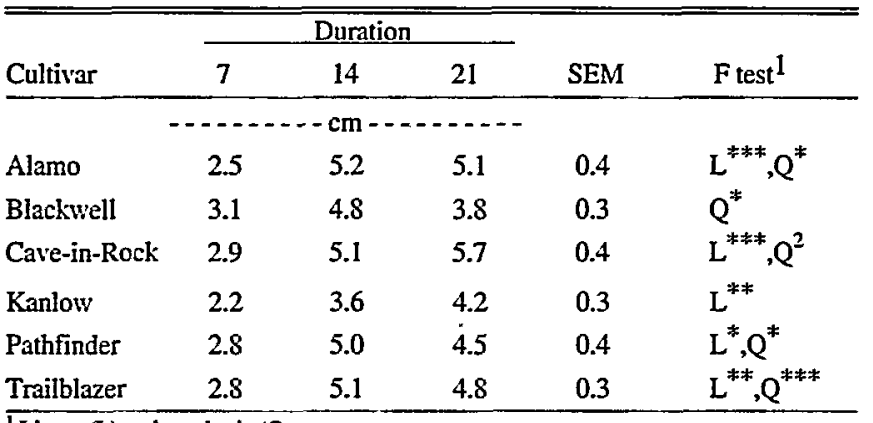

${ }^{1}$ Linear $(\mathrm{L})$ and quadratic $(Q)$ responses.

* $(P \leq 0.05), *(P \leq 0.01),{ }^{*}, \quad(P \leq 0.001)$.

${ }^{2}(P \leq 0.1)$

\section{Seed Size Distribution}

A positive, nonlinear relationship between seed weight and seed size class was also determined for all cultivars, except Cavein-Rock (Table 3). Whereas Cave-in-Rock showed a linear increase as seed size class increased, the increases for the other cultivars were nonlinear between the 60 to 80 seed size classes.

Table 3. Seed weight (mg/100 seed) for 6 switchgrass cultivars as affected by seed size.

\begin{tabular}{|c|c|c|c|c|c|c|c|}
\hline \multirow[b]{2}{*}{ Cultivar } & \multicolumn{3}{|c|}{ Seed Size Class } & \multirow[b]{2}{*}{70} & \multirow[b]{2}{*}{80} & \multirow[b]{2}{*}{ SEM } & \multirow[b]{2}{*}{ F test } \\
\hline & 40 & 50 & 60 & & & & \\
\hline & \multicolumn{6}{|c|}{$\ldots$} & \\
\hline Alamo & 57.2 & 82.8 & 112.6 & 122.2 & 135.9 & 1.8 & \\
\hline Blackwell & 67.7 & 104.3 & 146.0 & 175.8 & 204.6 & 0.3 & \\
\hline \multicolumn{8}{|l|}{ Cave-in- } \\
\hline Rock & 82.8 & 112.8 & 149.1 & 182.1 & 200.7 & 1.8 & $\mathrm{~L}^{*}$ \\
\hline Kanlow & 63.5 & 78.7 & 98.3 & 115.6 & 130.0 & 0.2 & \\
\hline Pathfinder & 60.3 & 93.3 & 138.8 & 171.0 & 195.0 & 0.6 & \\
\hline Trailblazer & & 154.1 & 162.2 & 184.8 & 210.8 & 0.6 & \\
\hline
\end{tabular}

Tinear (L) , quadratic (Q) and cubic (C) responses.

${ }^{\mp \mp}(P \leq 0.01),{ }^{\neq \mp}(P \leq 0.001),{ }^{\neq \neq \mp}(P \leq 0.001)$.

$2(P \leq 0.1)$.

\section{Germination of Sized Seed}

There was a nonlinear increase in germination percentage as a function of seed size for all cultivars, except Trailblazer after 7, 14, and 21 days (Table 4). Trailblazer germination was relatively high for all seed size classes. For the other cultivars, total germination percentage increased nonlinearly between the 40 and 80 seed size classes. Germination for the 40 seed size class was less than $10 \%$ for all cultivars, except Alamo and Kanlow. Thus, even though there was an increase in total germination percentage as seed size increased, the range in germination response was generally lower for Alamo and Kanlow than for the other cultivars. Pathfinder was the only cultivar with germination equal to or greater than $90 \%$ for the 70 and 80 seed size classes, which caused considerable range in germination between the lowest and highest seed size classes. 
Table 4. Germination of 6 switchgrass cultivars as affected by seed size.

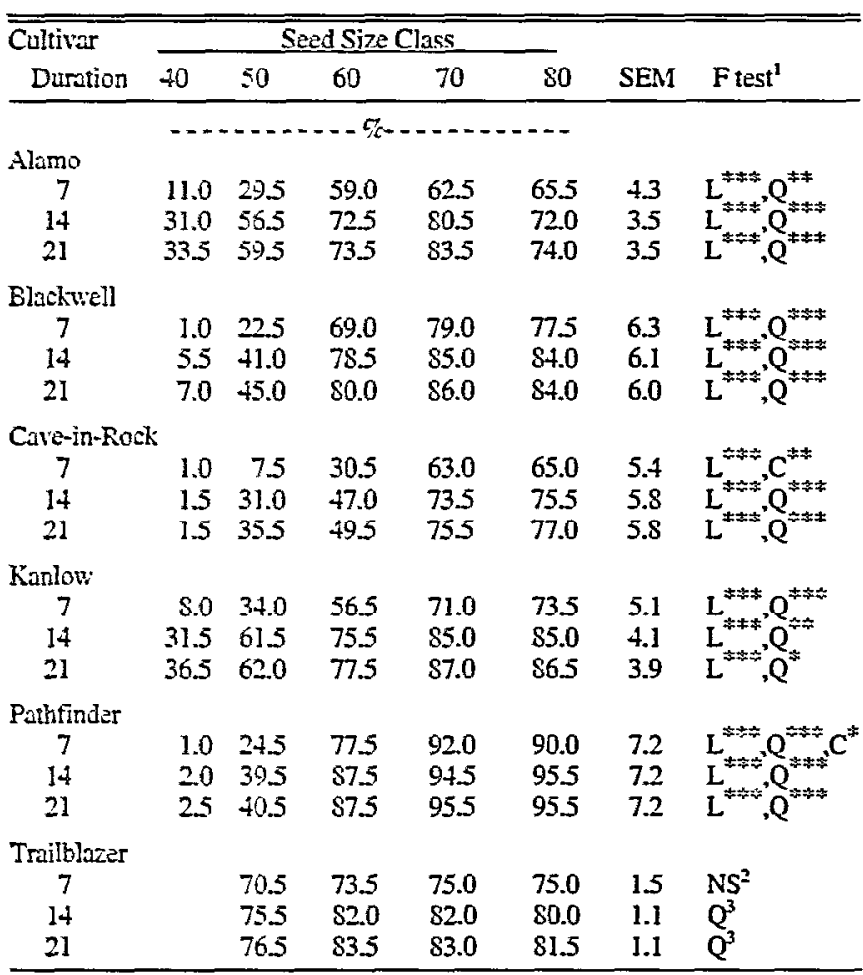

1 Linear ( $L$ ), quadratic $(Q)$, and cubic (C) responses.

* $(P 0.05),{ }_{*}(P \leq 0.01)$ *** $(P \leq 0.001)$.

Not significant $(P>0.1)$.

${ }^{3}(P \leq 0.1)$.

\section{Emergence of Sized Seed}

Emergence was relatively poor in the 2 silt-loam soils, particularly for the Taft soil. By 21 days, overall emergence was $15.1 \%$ for the Taft soil, $21.2 \%$ for the Leadvale soil, and $59.1 \%$ for the sand. There was a soil $\times$ seed size interaction $(P<0.01)$ on emergence after 7,14 , and 21 days (Table 5 ). There was a positive, nonlinear response to seed size in sand. Emergence in the 2 silt-loam soils was low at 7,14 , and 21 days, but did show a positive, linear response to seed size.

There was a soil $x$ seed size-class interaction $(P<0.01)$ for emergence at 7, 14, and 21 days. This was due to the poor emergence response to seed size in the 2 silt-loam soils. Emergence in the sand increased with an increase in seed size class for all cultivars, except Trailblazer (Table 6). There were nonlinear increases in emergence between the 60 and 70 seed size classes for Alamo, Blackwell, Cave-in-Rock.

Rock and Pathfinder; however, there was a linear increase in emergence as seed size class increased for Kanlow. Depth of planting did not affect emergence in either of the 2 silt-loam soils. For the sand, there was a nonlinear decline $(P<0.05)$ in emergence with greater planting depths on day 7 ; however, there was no response to planting depth by days 14 and 21 .

\section{Discussion}

Higher germination and emergence for the larger seed sizes was, for the most part, consistent among cultivars. This supports the conclusion by Boe and Johnson (1987) that cleaning the seed to increase the percentage of large seed and breeding for large seeded cultivars represent 2 potential methods for improving the consistency of switchgrass establishment. Kneebone and Cremer (1955) reported seed of Blackwell switchgrass less than $1.27 \mathrm{~mm}$ in diameter to have lower germination and seedling vigor than seed of greater diameter (Kneebone and Cremer, 1955). Mian and Nafziger (1994) reported a direct relationship between seed size of wheat (Triticum aestivum L.) and seedling shoot weight, root weight, and tiller number. Germination, and seedling root and shoot length for big bluestem also have been shown to be positively correlated with caryopsis size (Springer, 1991). Planting larger seed may improve germination and seedling vigor and, thus, improve the chances of successful establishment when conditions are less than ideal.

Greater coleoptile lengths for the continuous darkness treatment indicates that elongation and growth of switchgrass coleoptiles ceases once light is intercepted. Coleoptile length was maximum for most of the cultivars by 14 days. Energy was likely depleted at this time. The Kanlow seedlot had relatively shorter coleoptile length. Low seed weight for this seedlot of Kanlow indicates that there was relatively less energy for sustained growth however, Kanlow did exhibit extended growth beyond 14 days.

Results of these studies showed a strong relationship between seed size and both germination and emergence. For planting depths between 5 and $20 \mathrm{~mm}$, there appears to not be a relationship between switchgrass emergence and planting depths. Under the conditions of this experiment, however, emergence of switchgrass was enhanced when planted in the lighter textured soil.

Table 5. Emergence for 6 cultivars of switchgrass in a sand and 2 siltloam soils as affected by seed size.

\begin{tabular}{|c|c|c|c|c|c|}
\hline \multirow{2}{*}{$\begin{array}{l}\text { Soil } \\
\text { Duration }\end{array}$} & \multicolumn{3}{|c|}{ Seed Size Class } & \multirow[b]{2}{*}{ SEM } & \multirow[b]{2}{*}{$F$ test $^{1}$} \\
\hline & 50 & 60 & 70 & & \\
\hline & $\ldots$ & $-\%-$ & $\ldots .$. & & \\
\hline \multicolumn{6}{|l|}{ Sand } \\
\hline 7 & 29.7 & 50.8 & 60.4 & 0.3 & $L^{* * *}, Q^{* * *}$ \\
\hline 14 & 38.5 & 62.5 & 68.2 & 0.3 & $\mathrm{~L}^{* * *}, \mathrm{Q}^{* * * *}$ \\
\hline 21 & 41.1 & 64.8 & 71.6 & 0.3 & $L^{* * *}, Q^{* * *}$ \\
\hline \multicolumn{6}{|l|}{$\begin{array}{l}\text { Leadvale } \\
\text { silt loam }\end{array}$} \\
\hline 7 & 9.8 & 19.1 & 17.1 & 0.3 & $L^{*}$ \\
\hline 14 & 12.0 & 22.2 & 24.7 & 0.3 & $L^{* *}$ \\
\hline 21 & 12.8 & 24.1 & 26.7 & 0.3 & $\mathrm{~L}^{* *}$ \\
\hline \multicolumn{6}{|c|}{ Taft silt loam } \\
\hline 7 & 7.8 & 10.4 & 11.5 & 0.3 & $\mathrm{~L}^{2}$ \\
\hline 14 & 10.6 & 13.8 & 15.1 & 0.3 & $\mathrm{~L}^{2}$ \\
\hline 21 & 12.5 & 16.9 & 18.8 & 0.3 & $\mathrm{~L}^{2}$ \\
\hline
\end{tabular}

1 inear (L) and quadratic (Q) responses.

${ }^{\ddagger}(P \leq 0.05),{ }^{* \star}(P \leq 0.01),{ }^{* * *}(P \leq 0.001)$,

$2(P \leq 0.1)$. 
Table 6. Emergence in sand for 6 switchgrass cultivars as affected by secd size.

\begin{tabular}{|c|c|c|c|c|c|}
\hline \multirow{2}{*}{$\begin{array}{l}\text { Cultivar } \\
\text { Duration }\end{array}$} & \multicolumn{3}{|c|}{ Seed Size Class } & \multirow[b]{2}{*}{ SEM } & \multirow[b]{2}{*}{$F$ test $^{1}$} \\
\hline & 50 & 60 & 70 & & \\
\hline & $\cdots$ & $-50-$ & $-\ldots$ & & \\
\hline \multicolumn{3}{|l|}{ Alamo } & & 34 & $* 0^{2}$ \\
\hline 14 & 590 & 750 & 720 & 3.4 & * \\
\hline 21 & 62.3 & 76.7 & 75.3 & 3.1 & $\mathrm{~L}^{2}$ \\
\hline \multicolumn{6}{|l|}{ Blackwrell } \\
\hline 7 & 27.7 & 61.7 & 63.3 & 4.1 & $L^{* * *}, Q^{*}$ \\
\hline 14 & 36.7 & 70.0 & 68.7 & 4.0 & $L^{* * *}, Q^{*}$ \\
\hline 21 & 41.3 & 71.0 & 72.0 & 3.8 & $L^{\# * \neq}, Q^{2}$ \\
\hline \multicolumn{6}{|c|}{ Cave-in-Rock } \\
\hline 7 & 1.7 & 21.3 & 353 & 29 & $L^{\ddagger \neq *}, Q^{2}$ \\
\hline 14 & 2.3 & 30.3 & 46.3 & 3.5 & $\mathrm{~L}^{* \neq *}, \mathrm{Q}^{*}$ \\
\hline 21 & 3.3 & 32.7 & 48.3 & 3.6 & $L^{* * *}, Q^{*}$ \\
\hline \multicolumn{6}{|l|}{ Kanlow } \\
\hline 7 & 35.0 & 44.0 & 58.7 & 3.3 & $\mathbf{L}^{*}$ \\
\hline 14 & 44.3 & 57.3 & 65.7 & 3.2 & $L^{*}$ \\
\hline $\begin{array}{c}21 \\
\text { Parhfinder }\end{array}$ & 48.3 & 60.3 & 73.0 & 3.3 & $L^{* *}$ \\
\hline 7 & 18.7 & 58.7 & 83.0 & 4.9 & $L^{* * * *}$ \\
\hline 14 & 25.0 & 73.3 & $8 \$ .7$ & 4.9 & $\mathrm{~L}^{\neq \neq \neq}, \mathrm{Q}^{*}$ \\
\hline 21 & 27.7 & 78.0 & 90.3 & 4.8 & $\mathrm{~L}^{* \neq *}, \mathrm{Q}^{*}$ \\
\hline \multicolumn{6}{|l|}{ Trailblazer } \\
\hline 7 & 56.7 & 59.0 & 62.7 & 2.5 & $N S^{3}$ \\
\hline 14 & 63.7 & 69.0 & 68.0 & 2.5 & NS \\
\hline 21 & 63.7 & 70.0 & 73.3 & 2.5 & NS \\
\hline
\end{tabular}

\section{Literature Cited}

Boe, A., and P.O. Johnson. 1987. Deriving a large-seeded switchgrass population using air-column separation of parent seed. Crop Sci. 27:147-148.

Glewen, K.L., and K.P. Vogel. 1984. Partitioning the genetic variability for seedling growth in sand bluestem into its seed size and seedling vigor components. Crop Sci. 24:137-141.

Jensen, N.K., and A. Boe. 1991. Germination of mechanically scarified neoteric switchgrass seed. J. Range Manage. 44:299-301.

Kittock, D.L., and J.K. Patterson. 1962. Seed size effects on performance of dryland grasses. Agron. J. 54:277-279.

Kneebone, W.R., and C.L. Cremer. 1955. The relationship of seed size to seedling vigor in some native grass species. Agron. J. 47:472-477.

Littell, R.R., R.R. Freund, and P.C. Sector. 1991. SAS system for linear models. Third Ed. SAS Institute Inc., Cary, N.C.

Mian, M.A.R., and E.D. Nafziger. 1994. Seed size and water potential effects on germination and seedling growth of winter wheat. Crop Sci. 34:169-171.

Rogler, G. 1954. Seed size and seedling vigor in crested wheat. Agron. J. 46:216-220.

Springer, T.L. 1991. Caryopsis size and germination of Andropogon gerardii pedicellate and sessile spikelets. Seed Sci. Tech. 19:461-468.

Steel, R.F.D. and J.H. Torrie. 1980. Principles and procedures of statistics: A biometrical approach. 2nd Ed. McGraw-Hill Book Co. N.Y. 